\title{
The Impact of Tax Preferences on the Investment Attractiveness of Bonds for Retail Investors: The Case of Russia
}

\author{
Natalia B. Boldyreva ${ }^{1}$, Liudmila G. Reshetnikova ${ }^{1, * \mathbb{D}}$, Elena A. Tarkhanova ${ }^{1}$, \\ Zhanna V. Pisarenko ${ }^{2}$ and Svetlana A. Kalayda ${ }^{2}$ \\ 1 Department of Economics and Finance, University of Tyumen, 6, Volodarskogo Str., 625003 Tyumen, Russia; \\ n.b.boldyreva@utmn.ru (N.B.B.); e.a.tarkhanova@utmn.ru (E.A.T.) \\ 2 Department of Risk management and Insurance, Saint-Petersburg State University, 7-9, Universitetskaya \\ nab., 199034 St. Petersburg, Russia; z.pisarenko@spbu.ru (Z.V.P.); s.kalayda@spbu.ru (S.A.K.) \\ * Correspondence: reshetnikova-1@yandex.ru; Tel.: +79-123918414
}

Received: 24 February 2020; Accepted: 7 April 2020; Published: 13 April 2020

\begin{abstract}
The impact of tax incentives on the investment attractiveness of bonds for retail investors is assessed in the article. The paper presents a comparative empirical analysis of investment attractiveness of Russian bonds and bank deposits for domestic retail investors. We identify investment preferences of retail investors in Russia, analyze investment characteristics of deposits in Russian banks and a variety of bonds available for retail investors. Given the tax benefits of the recently introduced Individual Investment Account, we show that the real yield of investment in government bonds is over eight times higher than the yield of bank deposits. Despite higher risks of investing in bonds, we conclude that government bonds taking into account the tax benefits of the Individual Investment Account could be a realistic alternative to bank deposits for Russian retail investors.
\end{abstract}

Keywords: financial market; investment decisions; risk; banking; investor protection

\section{Introduction}

Investment is a necessary condition for the development of the national economy. Retail investors form a stable investment base in any country. The financial market mechanism redistributes the savings of retail investors to enterprises, contributing to the solution of strategic economic problems. In addition to a significant economic role, increasing the activity of retail investors in the financial market also plays a social role through the formation of additional household income, including pension income.

A specific feature of Russia's financial system is rather low activity of households in the financial market and the shift of their preferences towards investing in retail bank deposits that are extremely popular compared to securities. As of the end of 2016, the total number of individual investors in Russian stocks and bonds (residents of the Russian Federation) amounted to 1038 thousand which is only about $0.8 \%$ of the employable population (Tregub et al. 2016).

At the end of 2018, 52.5\% of Russian investors' assets in brokerage accounts were bonds (Eurobonds, corporate and government bonds), 25\% were shares of Russian corporations, and $22.5 \%$ were cash, mutual fund shares, exchange traded funds (ETFs), and other assets (NAUFOR 2018).

The Central Bank of the Russian Federation takes action to stimulate domestic investment and create favorable conditions for investment activity in the financial market (Bank of Russia 2016a). To develop the institution of the retail investor, the Russian government is using various mechanisms. 
Since 2015, any domestic investor who buys securities and keeps them for the period of 3 years does not pay personal income tax on the amount of the positive financial result received by the taxpayer in the tax period from the sale (repayment) of securities circulating on the organized securities market.

From 1 January 2015, the government introduced Individual Investment Accounts (the IIA) that can be opened with any broker company in the Russian Federation (RF). Using the Individual Investment Account, investors who are domestic tax residents receive a tax benefit. The tax benefit is a tax refund granted to the investor on the investment of up to 400,000 rubles during the year. With the current personal income tax rate of $13 \%$, the maximum amount of the return for the investor is 52,000 rubles per year. The main condition for getting the tax refund is holding the IIA for minimum 3 years.

Moreover, the Bank of Russia introduced categorizing of investors to protect retail non-qualified investors from risks in the financial market. The overwhelming majority of Russian citizens belong to the non-qualified investors group (Bank of Russia 2016b). Non-qualified investors are offered the least risky financial instruments traded on an organized market. Such instruments are bonds from the 1st and 2nd level quotation lists of the Moscow Stock Exchange, the main organized financial market in Russia. The bond is traditionally considered as an alternative to the deposit. The bond forms the expected cash flow similar to the cash flow generated by the deposit.

This study provides a quantitative assessment of the benefits for unqualified investors from using tax incentives connected with individual investment account.

The purpose of the paper is to determine how strong investment advantages bonds acquire in comparison with Bank deposits in order to change the situation on the Russian financial market and shift the preferences of unskilled investors towards investing in riskier financial instruments.

\section{Literature Review}

Analogs of Russian IIAs that provide tax incentives have existed on the financial markets of many countries for several decades: American IRAs, British ISA, Canadian TFSA, etc. (Cartano 2009; Hur 2010; Schreiner and Sherraden 2017; Kitao 2015; Zaman 2017). Households funded their IRA contributions from existing savings (Attanasio and DeLeire 2002). OECD provided an analysis of tax-preferred savings accounts in selected OECD countries (OECD 2007). A cross-country comparison of these accounts showed their benefits to high-income taxpayers who invest significant amounts of money. Ayuso, Jimeno, and Villanueva examined the incidence on household consumption of the introduction of tax incentives to retirement saving. They confirmed that most contributions to pension funds are by older and high-income individuals (Ayuso et al. 2019).

Foreign researchers pay great attention to the impact of taxes on investments. Their research focuses on the relationship between tax and decision-making, investment volume, and a firm's value (Fama and French 1998; Romer and Romer 2010). Taxes are included in financial asset valuation models (Litzenberger and Ramaswamy 1979; Belomyttseva et al. 2018b). Foreign authors have studied the effectiveness of tax incentives for accounts similar to IIA (Milligan 2012; Attanasio et al. 2004). In Russian publications was studied only some general questions of taxes impact on private investment (Karzanova 2002; Lazaryan and Chernotalova 2017). The issues of investing in securities on the Russian financial market, taking into account the advantages of IIAs for retail investors, have not yet been fully investigated.

Tax-benefits accounts allow you to invest in a wide range of financial instruments and use various investment strategies. It is well documented in the financial literature that retail investors who trade stocks do not increase risk-adjusted returns (Fjesme 2019). They lose some of the income generated by the stock market (Barber and Odean 2000). Trading stocks for taxable investments is dangerous for the wealth of private investors (Odean 1998).

In the Russian financial market, there are various securities for retail investors. Retail investors can choose securities with an acceptable return-risk ratio. They can also form internationally diversified investment portfolios (Boldyreva et al. 2019). The choice of specific financial instruments by individuals' investors is determined by their investment preferences. Kahneman and Tversky proved that in 
decision-making concerning gains people prefer to choose a more guaranteed result in spite of the fact that the probabilistic result involving risk could bring a bigger gain (Kahneman and Tversky 1979). They suggested that "... a riskless prospect is preferred to a risky prospect of equal or greater expected value" (Tversky and Kahneman 1981). Chechin and Novikov studied and summarized the process of making an investment decision in the Russian Federation securities market and identified criteria that determine the investment preferences of Russian retail investors (Chechin and Novikov 2016).

Niklewski and Redhead argued that in terms of diversification over the term of investment, bank deposits and bonds are suitable for short-term and medium-term investments, as opposed to stocks that are more suitable for long-term investments (Niklewski and Redhead 2013). The works of many authors are devoted to the evaluation of investments in financial instruments, including bonds. Fixed income financial instruments and the risks of investing in bonds are described in detail, for example by Fabozzi (Fabozzi 2015).

Russian authors mainly studied the issue aspects of the Russian bond market. Research papers usually address the problems of the bond market functioning as an instrument of the state's debt policy (Belyakov 2017; Zapevalova 2017), regions of the Russian Federation, municipalities (Ermakova et al. 2016; Miller and Miller 2015), corporations (Alekseeva and Makarova 2017). The investment aspect of the Russian bond market has been studied for institutional investors (Abramov et al. 2015; Inozemtsev and Tarasov 2018). In Russian journals there are publications on IIA and bonds as a promising and effective instrument for investment with IIA (Lakhno 2015). Features of applying tax incentives for individual investors in Russian Federation bonds are considered by Belomyttseva et al. (Belomyttseva et al. 2018a).

The liberalization of taxation of retail investors contributes to the development of the securities market and encourages savings. However, the effectiveness of IIA tax incentives for retail investors in the Russian Federation has not yet been studied or measured due to data limitations.

\section{Methodology and Data}

Based on a literature review and taking into account tax innovations, the authors test the hypothesis that bonds receive strong investment benefits for retail investors, taking into account the tax benefits of the Individual Investment Account compared to the bank deposit. This may shift the preferences of unqualified investors towards investing in bonds and change the situation on the Russian financial market.

We test our hypothesis under the following assumption about investment behavior of a retail investor: (a) low risk tolerance, which limits the choice of bonds from the Moscow exchange's first and second level quotation lists; (b) passive investment strategy; (c) the use of the IIA tax benefits; (d) from 400 thousand rubles up to 1200 thousand rubles as the amount of investment; (e) at least 3-year investment horizon.

Testing the hypothesis, we used the traditional approach to the investment attractiveness evaluation of bonds in comparison with deposits in the "risk-yield" coordinate system. Higher risk implies higher returns. The return on investment is reduced due to transaction and tax costs. This is why we have shown the income taxation specifics of retail investors in bonds and deposits, as well as transaction costs of investors in bonds. Then we showed that investments in bonds are associated with greater risks. It means they should give a higher return compared with deposits.

Our comparative empirical analysis includes investment characteristics research of bank deposits in Russian banks and those of the bonds traded on the stock market of the Moscow Exchange Group. The investor is interested in the real return on investment. That is why we used the Fischer formula (Sharpe et al. 1999).

As a result, we show how the using of IIA changes the balance of power in the investment market, and greatly increases the government bonds investment's attractiveness in comparison with Bank deposits. To do this, we use traditional methods of investment theory. We calculated the maximum tax 
deduction yield as an Internal Rate of Return of the cash flow to an IIA (r) (Sharpe et al. 1999), using the model (1):

$$
V+\frac{V-V \times t}{1+r}+\frac{V-V \times t}{(1+r)^{2}}+\ldots+\frac{V-V \times t}{(1+r)^{(n-1)}}=\frac{V \times n+V \times t}{(1+r)^{n}}
$$

where $V$-the amount of investment using IIA at the beginning of year; $t$ - the personal income tax rate; $n$-the term of investment using the IIA, in years.

The methodological basis of the research also relates to such scientific methods of cognition as induction and deduction, analysis and synthesis, comparison and systematic approach.

We analyzed the data from RF Federal State Statistics Service concerning savings in bank deposits and securities in RF in 2012-2018. Data sources are Russian Federation Federal State Statistics Service, Bank of Russia, Moscow Exchange, etc.

\section{Results and Discussion}

Table 1 shows that most Russian citizens obviously prefer bank deposits for their savings. Though the data show increase of savings in securities in the last years under consideration, nevertheless, share of savings in bank deposits is still much higher than that of securities. Data for 2018 is not considered due to a change in the methodology of Russian Federation Federal State Statistics Service.

Table 1. Savings of the Russian Federation (RF) Population in Bank Deposits and Securities (per year).

\begin{tabular}{|c|c|c|c|c|c|c|}
\hline Indicator & 2012 & 2013 & 2014 & 2015 & 2016 & 2017 \\
\hline $\begin{array}{l}\text { Savings in Bank Deposits and } \\
\text { Securities, bln Rub }\end{array}$ & 2467 & 2808 & 378 & 3453 & 2873 & 2706 \\
\hline $\begin{array}{l}\text { Savings growth rate to the } \\
\text { previous year, } \%\end{array}$ & - & 13.82 & -86.54 & 813.49 & -16.80 & -5.81 \\
\hline \multicolumn{7}{|l|}{ Including: } \\
\hline Savings in Bank Deposits, bln Rub & 2052 & 2242 & -309 & 2648 & 2125 & 2169 \\
\hline $\begin{array}{l}\text { Share of Bank Deposits in Savings } \\
\text { (Bank Deposits and Securities), \% }\end{array}$ & 83.18 & 79.84 & -81.75 & 76.69 & 73.96 & 80.16 \\
\hline Savings in Securities, bln Rub & 415 & 566 & 687 & 805 & 748 & 537 \\
\hline $\begin{array}{l}\text { Share of Securities in Savings } \\
\text { (Bank Deposits and Securities), \% }\end{array}$ & 16.82 & 20.16 & 181.75 & 23.31 & 26.04 & 19.84 \\
\hline
\end{tabular}

The crisis in the Russian economy in 2014 led to a strong devaluation of the Russian ruble and a reduction in household income. This forced Russian citizens to withdraw their savings, which fell by $86.54 \%$ compared with the previous year. In the following year, Russian citizens returned to their previous strategy of creating savings. The introduction of IIAs in 2015 did not lead to a noticeable change in the savings strategy of the population during the analyzed period.

\subsection{Comparative Analysis of Investment Characteristics of Deposits and Bonds Based on the Retail Investor's Preferences}

To ensure the comparability of the financial instruments under consideration, we have reviewed the investment characteristics of bank deposits and bonds taking into account the preferences of the retail investor.

The incomes taxation of deposits and bonds greatly influences the returns on the investment. Table 2 shows the comparative incomes taxation of Russian retail investors in bonds and deposits. 
Table 2. Incomes taxation of Russian retail investors in Bonds and Deposits, \%.

\begin{tabular}{|c|c|c|c|c|}
\hline Financial Instrument & $\begin{array}{l}\text { Interest Income } \\
\text { Below the Bank of } \\
\text { Russia's Key Rate } \\
\text { Increased by 5\% }\end{array}$ & $\begin{array}{c}\text { Interest Income } \\
\text { Exceeding the } \\
\text { Bank of Russia's } \\
\text { Key Rate } \\
\text { Increased by 5\% }\end{array}$ & Capital Gain & Note \\
\hline Corporate bond & 0 & 35 & 13 & $\begin{array}{c}\text { tax free, if the } \\
\text { investment is } \\
\text { longer than } 3 \text { years }\end{array}$ \\
\hline $\begin{array}{l}\text { Government bond and } \\
\text { municipal bond }\end{array}$ & 0 & 0 & 13 & $\begin{array}{c}\text { tax free, if the } \\
\text { investment is } \\
\text { longer than } 3 \text { years }\end{array}$ \\
\hline Bank Deposit & 0 & 35 & - & - \\
\hline
\end{tabular}

According to the Tax Code of the RF the deposit income is not subject to personal income tax if the interest rate on the deposit does not exceed the key rate of the Bank of Russia, increased by 5 percentage points. In fact, incomes from bank deposits are not being taxed because banks offer interest rates below the key rate of the Bank of Russia.

The income of an individual in the form of a coupon yield on a bond is subject to tax relief (See Table 2). At the same time, the income in the form of capital gain on the sale of a bond is subject to personal income tax ( $13 \%$ for domestic tax residents). In addition, the investor pays transaction costs: commission fees of the broker, the stock exchange and depository. The commission fee of the Moscow Exchange Group (2018) for transactions with bonds does not exceed $0.01 \%$.

The fee of the broker depends on the tariff plan and the volume of transactions. We analyzed the current data of the leading brokers on the stock market of the Moscow Exchange (BrokerCreditService Company, Otkritie Broker, Finam, Renessans Broker, Sberbank, etc.) and found out that their fees do not exceed $0.0125 \%$ of the turnover, an average of $0.0559 \%$ for the investment from 400 thousand rubles up to 1200 thousand rubles.

The depository fee is also varied and depends on the service provider. For example, the depositary fee of Sberbank is zero rubles. The depositary of Otkritie Broker charges 175.0 rubles per month if there is movement on the depo account. Given the passive investment management strategy that is characteristic of retail investors, transaction costs do not have a significant impact on the return on investment in bonds.

The risks associated with deposits and bonds are also different. Fabozzi gave a detailed description of the risks of investment in bonds (Fabozzi 2015). We conducted a comparative analysis of the investment risks in bonds and deposits in RF (Table 3).

Table 3. Investment Risks in Bonds and Deposits in the Russian Federation (RF).

\begin{tabular}{ccc}
\hline Risk & Deposits & Bonds \\
\hline Inflation Risk & yes & yes \\
Liquidity Risk & yes & yes \\
Market Risk & no & yes \\
Interest Rate Risk & yes & yes \\
Reinvestment Risk & no & yes \\
Risk of Early Recall & no & yes \\
Credit Risk & yes & yes \\
Operational Risk & no & yes \\
\hline
\end{tabular}

Source: compiled by the authors. 
In Russia, the state guarantees the return of bank deposits to individuals in the amount of up to 1400 thousand rubles. This suggests a low credit risk on deposits at the level of sovereign risk. However, compensation does not always ensure the return of interest money in full, which depends on the deposit conditions in each bank. Many banks offer preferential conditions for early deposit termination, which allow to get from $1 / 2$ to $2 / 3$ of the initial income. Otherwise, depositors almost completely lose their income and, thus, the liquidity risk of Bank deposits is realized.

In the bond market, the credit risk depends on the issuer. Government bonds have the lowest credit risk.

Table 3 shows that typical risks in the bond market are market risk, the risk of reinvestment, the risk of early withdrawal (call risk), and operational risk. The investors in government bonds can only escape the market risk if they find the bonds with the suitable Maturity Date, which is not always an easy task. In modern Russian conditions, operational risk for retail investors is associated with the activities of financial market professionals (brokers, depositories, etc.).

Taking into account additional risks, transaction costs, and peculiarities of income taxation, investments in bonds should show higher yields to be considered as an alternative to the deposit with similar characteristics by the term and amount of investment.

\subsection{Empirical Analysis of the Russian Deposit and Bond Market}

The modern Russian deposit market is characterized by a large and diverse offer. We investigated the dynamics of interest rates on bank deposits and inflation (Table 4).

Table 4. Interest Rates on Bank Deposits of Individuals and the Inflation Rate in Russia, \% per year.

\begin{tabular}{ccccccccc}
\hline Indicator & $\mathbf{2 0 1 2}$ & $\mathbf{2 0 1 3}$ & $\mathbf{2 0 1 4}$ & $\mathbf{2 0 1 5}$ & $\mathbf{2 0 1 6}$ & $\mathbf{2 0 1 7}$ & $\mathbf{2 0 1 8}$ & CAGR \\
\hline $\begin{array}{c}\text { Average interest rates on bank } \\
\text { deposits from 1 to 3 years }\end{array}$ & 7.7 & 7.86 & 8.14 & 10.23 & 8.42 & 6.96 & 6.23 & 7.93 \\
$\quad \begin{array}{c}\text { Rate of Inflation } \\
\text { Real yield on bank deposits }\end{array}$ & 6.57 & 6.47 & 11.35 & 12.91 & 5.39 & 2.51 & 4.26 & 7.01 \\
\hline
\end{tabular}

Source: compiled by the authors, based on the data of Federal State Statistic Service of Russia and Bank of Russia.

As Table 4 shows, in 2014 and 2015 bank deposits showed negative real yields. On average, real yield on deposits was less than $1 \%(0.86 \%)$ per year. An investor placing funds in bank deposits assumes a high inflation risk.

The main organized bond market in Russia is represented by the Moscow Exchange Group. Currently, for retail investors, the Moscow Exchange Group offers bonds (from the first and second level quotation lists) in a number of segments: Government bonds, Regional and Municipal bonds, Russian Corporate bonds denominated in rubles. We analyzed investment attractiveness of the segments for the retail investor.

The main indicators for the secondary bond market of the Moscow Exchange are presented in Table 5.

Regional and Municipal bond market is not presented in Table 5. Observations have shown that this market remains in deep stagnation being the most illiquid and insignificant sector of the Russian debt market.

In terms of trading volume, corporate and government bonds occupy leading positions. The issue of corporate bonds is one of the most common ways (particularly for large financial and non-financial corporations) of attracting capital to the Russian Federation, providing a wide choice for retail investors (See Table 5). The corporate bond market surpasses the government bond market in terms of profitability, but is inferior to it in terms of volatility (market risk). One of the reasons for the high volatility of the Russian government bond market is a large proportion of foreign investors. CAGR of the index of the Russian government bonds was $7.77 \%$ which is slightly less than CAGR of the bank 
deposit of $7.93 \%$ (Table 4), with the real yield of the index of the Russian government bonds of $0.71 \%$, and the real interest rate of the bank deposit of $0.86 \%$.

Table 5. Indicators for the Secondary Bond Market of the Moscow Exchange.

\begin{tabular}{|c|c|c|c|c|c|c|c|c|}
\hline Indicator & 2012 & 2013 & 2014 & 2015 & 2016 & 2017 & 2018 & CAGR \\
\hline \multicolumn{9}{|c|}{ Russian government bond market } \\
\hline Number of issues, pcs. * & 34 & 36 & 32 & 37 & 38 & 40 & 38 & - \\
\hline $\begin{array}{l}\text { Trading volume at actual value, } \\
\text { billion rubles* }\end{array}$ & 4590 & 5998 & 3877 & 3577 & 4961 & 6570 & 7100 & - \\
\hline Average annual turnover ratio, $\%$ & 143 & 170 & 91 & 70 & 86 & 98 & 94 & - \\
\hline $\begin{array}{l}\text { Volatility index of government } \\
\text { bonds MCX RGBI TR,\% }\end{array}$ & 0.17 & 0.32 & 0.81 & 0.56 & 0.28 & 0.15 & 0.27 & - \\
\hline $\begin{array}{l}\text { Yield of government bond index } \\
\text { MCX RGBI TR,\% }\end{array}$ & 10.86 & 3.8 & -14.36 & 29.56 & 14.82 & 12.79 & 2.12 & 7.77 \\
\hline \multicolumn{9}{|c|}{ Corporate Bond Market } \\
\hline Number of Russian issuers * & 308 & 328 & 323 & 349 & 337 & 335 & 330 & - \\
\hline $\begin{array}{l}\text { Number of issues/in quotation lists } \\
\text { of levels } 1 \text { and } 2 \text {, pcs.* }\end{array}$ & $788 / 555$ & $926 / 512$ & $931 / 409$ & $1030 / 367$ & $1088 / 382$ & $1171 / 445$ & $1195 / 475$ & - \\
\hline $\begin{array}{l}\text { Trading volume at actual value, } \\
\text { billion rubles *** }\end{array}$ & 5767 & 6662 & 4725 & 4952 & 4628 & 4408 & 3100 & - \\
\hline Average annual turnover ratio, $\%$ ** & 136 & 129 & 73 & 63 & 51 & 40 & 25 & - \\
\hline $\begin{array}{l}\text { Volatility index of corporate bonds } \\
\text { MCX CBI TR,\% }\end{array}$ & 0.06 & 0.05 & 0.31 & 0.30 & 0.13 & 0.13 & 0.16 & - \\
\hline $\begin{array}{l}\text { Yield of corporate bond index MCX } \\
\text { CBI TR, } \%\end{array}$ & 8.57 & 8.81 & -1.43 & 18.75 & 10.79 & 12.28 & 4.42 & 8.73 \\
\hline
\end{tabular}

Note: * as of the end of the year; ${ }^{* *}$ To calculate the trading volume, the turnover ratio, regional and municipal bonds are combined into one group with corporate bonds. Regional and municipal bonds are usually considered together because of the very small share in the domestic debt market (less than $4 \%$ ). Source: compiled by the authors, based on the data of NAUFOR.

The liquidity of the secondary bond market can be judged by a number of indicators, including the number of issuers, trading volume, and turnover ratio. Table 5 shows that since 2012 the government securities market has been more liquid. In contrast, the turnover ratio of corporate, regional, and municipal bonds has been demonstrating a long-term declining trend; it has decreased 5.4 times since 2012.

The market of government bonds is represented by federal loan bonds (FLB). The issuer of government bonds is the Ministry of Finance of Russian Federation. The federal loan bonds market is represented by various species of bonds. The FLB sector is quite liquid. At the same time, the spread of the number and trading volume is quite large. The liquidity of the government bond sector is provided by FLBs with fixed and floating coupons. The face value of all FLBs is 1000 rubles. At their redemption, the owner of FLBs receives the face value and the coupon income. The coupon income of FLBs paid periodically (usually twice a year). These bonds may be more interesting to retail investors.

According to the Moscow Exchange, the period 2016-2018 showed the increased default activity of the corporate bonds market. We estimated the number of corporate bond defaults (technical defaults included) at 8 (in 2016), at 12 (in 2017), and at 23 (in 2017).

We have found that government bonds are the most liquid instrument on the RF bond market. Credit risk of investing in FLBs is minimal; it is limited by the sovereign risk. Thus, government bonds are the most attractive for retail investors in the Russian bond market. At the same time, we found that other risks, highlighted in the Section 4.1, are inherent in the government bond market. 
We conducted an empirical analysis of the Russian domestic bond and deposit market and concluded that government bonds are losing out to Bank deposits in terms of risk-adjusted returns. The Russian retail investor makes the right choice in favor of a Bank Deposit, if not taking into account the tax benefits of the IIA.

\subsection{The Impact of Tax Preferences on the Government Bonds Investment Attractiveness}

We calculated the maximum tax deduction yield as an Internal Rate of Return of the cash flow to an IIA, under the following assumptions:

(a) during three years, at the beginning of each year, the investor transfers 400 thousand rubles to the IIA, which are at the account until the end of the third year;

(b) at the end of the first and second years, the investor uses tax deduction in the amount of 52 thousand rubles to reduce the amount of the money for the following investment to 348 thousand rubles;

(c) at the end of the third year, the investor receives the last tax deduction of 52 thousand rubles and closes the IIA, withdrawing 1200 thousand rubles from the account.

Under the assumptions made, we find the effective yield of the maximum tax deduction solving the Equation (1):

$$
\begin{gathered}
400+\frac{400-400 \times 0.13}{1+r}+\frac{400-400 \times 0.13}{(1+r)^{2}}=\frac{400 \times 3+400 \times 0.13}{(1+r)^{3}} \\
400+\frac{400-52}{1+r}+\frac{400-52}{(1+r)^{2}}=\frac{1200+52}{(1+r)^{3}} \\
r=6.64 \%
\end{gathered}
$$

According to the legislation, the investor receives from the state an annual tax refund in the amount of 52 thousand rubles. Such cash flow within three years creates an additional yield of $6.64 \%$. When evaluating the attractiveness of investments in bonds, we took into account the maximum tax benefits that the investor who opens the IIA receives (see Table 6).

Table 6. Comparative Efficiency of Investment in Government Bonds and Deposits, \% per year.

\begin{tabular}{ccc}
\hline Indicator & Deposits & Bonds \\
\hline Average Yield & 7.93 & 7.77 \\
Yield of the IIA & - & 6.64 \\
Average Yield & 7.93 & 14.41 \\
with IIA Benefits Included & 7.01 & 7.01 \\
Average Inflation rate & 0.86 & 6.92 \\
Average Inflation-Adjusted Yield & - & Market Risk, Reinvestment risk, Operational Risk \\
Additional Risks & . &
\end{tabular}

Source: compiled by the authors.

The Table 6 shows that the average yield of investment in government bonds (with IIA benefits included) is $14.41 \%$. Average inflation-adjusted yield of the investment in government bonds (using the IIA) is over eight times higher than the yield of deposits.

We confirmed our hypothesis. The bonds receive strong investment benefits for retail investors, taking into account the tax benefits of the Individual Investment Account compared to the bank deposit. This may shift the preferences of unqualified investors towards investing in bonds and change the situation on the Russian financial market.

According to the Moscow Exchange, the dynamics of the investors' number who opened IIA confirms the positive impact of tax innovations on the Russian financial market. The number of retail investors is almost 2 million people, and the number of open IIA by the end of 2018 has grown to almost 600 thousand, but only $45.5 \%$ of IIAs has funded. According to Table 1, the implementation of IIA did not lead to an increase in the share of securities in savings in the analyzed period. 
In our opinion, the reasons for the low involvement of Russian citizens in securities transactions are the following: insufficient monetary income of the population, low financial literacy, distrust of the securities market, etc. These assumptions require further research.

\section{Conclusions}

In the Russian Federation, retail investors make up a small share in the securities market, despite the efforts of the Bank of Russia to stimulate the domestic investors and create favorable conditions for their activities. Our analysis shows that the overwhelming majority of RF potential retail investors prefer bank deposits for saving. From 2012 to 2017, deposits accounted for average 79\% of household savings. In the paper, we conducted a comparative analysis of the investment attractiveness of bank deposits and bonds for retail investors in the Russian Federation, taking into account their investment preferences. In our opinion, typical Russian retail investors have low tolerance for risk. They might be interested in tax benefits of the IIA and are likely to pursue passive investment strategy. We analyzed the investment characteristics of deposits and bonds and justified that investment in bonds should show a higher yield to be an alternative to the deposit. The reason for a higher yield of bonds is additional risks, income taxation and transaction costs.

The bond market is one of the largest on the Moscow Exchange Group. Currently, the bond market for retail investors has a number of segments: Government bonds, Regional and Municipal bonds, and Corporate bonds. We have conducted an empirical analysis of the Russian domestic bond market and concluded that only government bonds might be attractive investments for the retail investor.

The Russian government bond market shows a lower yield compared to the corporate bond market, but has a higher volatility. In our opinion, the volatility of the government bond market is related to the behavior of foreign investors.

The market of Government bonds is the most liquid. The real yield of this market slightly inferior the real yield of bank deposits. Bank deposits provide an average inflation-adjusted yield of $0.86 \%$ per annum. The real yield of the index of the Russian government bonds was $0.71 \%$. Deposits are more attractive than government bonds in terms of risk-adjusted returns if you do not use the tax preferences associated with IIS. We calculated the effectiveness of IIA tax preferences at $6.64 \%$. Taking into account the tax benefits provided by the IIA, the average inflation-adjusted yield of investments in Government bonds is over eight times higher than that for bank deposits. At the same time, the risk of investing in bonds is higher. It is only the investor who can judge if the return on investment in bonds will compensate the risk. In our opinion, government bonds, taking into account the tax benefits of individual investment accounts, receive strong investment benefits for retail investors compared with the bank deposit. This may shift the preferences of unqualified investors towards investing in bonds and change the situation on the Russian financial market under the certain conditions.

Author Contributions: All the authors have contributed equally to the paper. All authors have read and agreed to the published version of the manuscript.

Funding: This research received no external funding.

Conflicts of Interest: The authors declare no conflict of interest.

\section{References}

Abramov, Alexander, Ksenya Akshentseva, and Alexander Radygin. 2015. Efficiency of mutual funds: theoretical approaches and experience of Russia. Economic Policy 10: 60-86. Available online: http://ecpolicy.ru/pdf/ 2015-4/abramov_4_2015.pdf (accessed on 23 February 2020). [CrossRef]

Alekseeva, Irina A., and Elizaveta V. Makarova. 2017. Russian corporate bond market: trends and development prospects. Bulletin of Baikal State University 27: 389-400. [CrossRef]

Attanasio, Orazio P., and Thomas DeLeire. 2002. The Effect of Individual Retirement Accounts on Household Consumption and National Saving. The Economic Journal 112: 504-38. [CrossRef] 
Attanasio, Orazio P., James Banks, and Matthew Wakefield. 2004. Effectiveness of tax incentives to boost (retirement) saving: theoretical motivation and empirical evidence. OECD Economic Studies 39: 145-72. Available online: https://www.oecd.org/unitedkingdom/35664068.pdf (accessed on 23 February 2020).

Ayuso, Juan, Juan F. Jimeno, and Ernesto Villanueva. 2019. The effects of the introduction of tax incentives on retirement saving. SERIEs 10: 211-49. [CrossRef]

Bank of Russia. 2016a. Guidelines for the Development of the Russian Financial Market in 2016-2018. Moscow: Bank of Russia. Available online: https://cbr.ru/Content/Document/File/44188/onrfr_2016-18.pdf (accessed on 23 February 2020).

Bank of Russia. 2016b. Improving the System of Investor Protection in the Financial Market by Introducing Regulation of the Categories of Investors and Determining their Investment Profile. Moscow: Bank of Russia. Available online: https://cbr.ru/Content/Document/File/50723/report_30062016.pdf (accessed on 23 February 2020). (In Russian)

Barber, Brad M., and Terrance Odean. 2000. Trading is Hazardous to Your Wealth: The Common Stock Investment Performance of Individual Investors. Journal of Finance 19: 773-806. [CrossRef]

Belomyttseva, Olga S., Larisa S. Grinkevich, Anastasiia M. Grinkevich, Samo Bobek, and Polona Tominc. 2018a. Tax incentives for bond-oriented individual investors: evidence from the Russian Federation. Journal of Tax Reform 4: 108-24. [CrossRef]

Belomyttseva, Olga, Larisa Grinkevich, and Anastasiia Grinkevich. 2018b. A note on the Gordon growth model with taxes. In The Impact of Globalization on International Finance and Accounting. Edited by Procházka D. Springer Proceedings in Business and Economics. Cham: Springer, pp. 153-59. [CrossRef]

Belyakov, Igor V. 2017. On factors that determine the spreads of sovereign Eurobonds in Russia. Economic Policy 12: 200-25. [CrossRef]

Boldyreva, Natalia B., Liudmila G. Reshetnikova, and Valeria Cheymetova. 2019. Personal financial investments: leading trends and growth factors. In The 3rd International Conference on Social, Economic, and Academic Leadership (ICSEAL 2019). Paris: Atlantis Press, vol. 318, pp. 112-18. [CrossRef]

Cartano, David J. 2009. Taxation of Individual Retirement Accounts. CCH a Wolters Kluwer Business. Available online: https://www.goodreads.com/book/show/7258659-taxation-of-individual-retirement-accounts-2009 (accessed on 23 February 2020).

Chechin, Vladimir V., and Alexander V. Novikov. 2016. Investment Preferences as Basis in Decision-Making Process in the Securities Market. Vestnik NSUEM 4: 103-13. Available online: https://nsuem.elpub.ru/jour/ article/view/819?locale=en_US (accessed on 23 February 2020).

Ermakova, Elena A., Yuliya V. Semernina, and Alexander A. Shcherbakov. 2016. Improving the efficiency of the Russian sub-Federal bond market. Journal of New Economy 63: 23-33. Available online: http: //jne.usue.ru/ru/-2016/501 (accessed on 23 February 2020).

Fabozzi, Frank J. 2015. Bond Markets, Analysis and Strategies. Hoboken: Pearson Education. Available online: https://www.goodreads.com/book/show/6766319-bond-markets-analysis-and-strategies (accessed on 23 February 2020).

Fama, Eugene F., and Kenneth R. French. 1998. Taxes, financing decisions, and firm value. The Journal of Finance 53: 819-43. Available online: http://ecsocman.hse.ru/data/873/126/1231/fama_french_-_taxes_and_value_ 1998.pdf (accessed on 23 February 2020). [CrossRef]

Fjesme, Sturla L. 2019. Retail investor experience, asset learning, and portfolio risk-adjusted returns. Finance Research Letters, October 13. [CrossRef]

Hur, Mann H. 2010. A comparative study of the relationship between pension plans and individual savings in Asian countries from an institutional point of view. International Journal of Social Welfare 19: 379-89. [CrossRef]

Inozemtsev, Eduard V., and Evgeni B. Tarasov. 2018. Actively managed Russian mutual funds: Good or bad for investors? Economic Issue 3: 64-79. [CrossRef]

Kahneman, Daniel, and Amos Tversky. 1979. Prospect Theory: an Analysis of Decision under Risk. Econometrica 47: 263-91. Available online: https://ssrn.com/abstract=1505880 (accessed on 23 February 2020). [CrossRef]

Karzanova, Irina V. 2002. Estimation of effect of taxation on real sector investment in Russia: Calculation of marginal effective tax rates. Economic Journal of HSE 6: 225-50. Available online: https://ej.hse.ru/2002-6-2/ 26547895.html (accessed on 23 February 2020). 
Kitao, Sagiri. 2015. Pension reform and individual retirement accounts in Japan. Journal of the Japanese and International Economies 38: 111-26. [CrossRef]

Lakhno, Yuliya V. 2015. Possibilities and limitations of mechanism of investment through personal investment account. Tax and Finance 2: 7-13. Available online: https://www.nalogprof.ru/nalogi-i-finance-contents/ ?page=\&id_article=75 (accessed on 23 February 2020).

Lazaryan, Samvel S., and Mariya A. Chernotalova. 2017. Taxes impact on private investment. Finansovyj žhurnal Financial Journal 3: 71-84. Available online: https://ideas.repec.org/a/fru/finjrn/170306p71-84.html (accessed on 23 February 2020).

Litzenberger, Robert H., and Krishna Ramaswamy. 1979. The effect of personal taxes and dividends on capital asset prices: theory and empirical evidence. Journal of Financial Economics 7: 163-95. [CrossRef]

Miller, Alexander E., and Andrey A. Miller. 2015. Evaluating the role of the securities market in increasing regional budget revenues. Economy of Region 3: 216-27. [CrossRef]

Milligan, Kevin. 2012. Policy Forum: The Tax-Free Savings Account - Introduction and Simulations of Potential Revenue Costs. Canadian Tax Journal/Revue Fiscale Canadienne 60: 355-60. Available online: https://www.ctf.ca/ctfweb/EN/Publications/CTJ_Contents/2012CTJ2.aspx (accessed on 23 February 2020).

NAUFOR. 2018. Russian stock market 2012-2018. In National Association of Stock Market Participants. Available online: https://naufor.ru/getfile.asp?id=12775 (accessed on 23 February 2020).

Niklewski, Jacek, and Keith Redhead. 2013. Time Diversification Frontiers and Efficiency Frontiers: Implications for Long-Term Portfolio Management. The Journal of Wealth Management 16: 31-42. [CrossRef]

Odean, Terrance. 1998. Are Investors Reluctant to Realize Their Losses? Journal of Finance 53: 1775-98. [CrossRef]

OECD. 2007. Encouraging Savings through Tax-Preferred Accounts. Paris: OECD Publishing, 126p. [CrossRef]

Romer, Christina D., and David H. Romer. 2010. The macroeconomic effects of tax changes: Estimates based on a new measure of fiscal shocks. American Economic Review 100: 763-801. [CrossRef]

Schreiner, Mark, and Michael Sherraden. 2017. Can the Poor Save? Saving and Asset Building in Individual Development Accounts. Abingdon: Routledge, 385p. Available online: https://www.goodreads.com/book/ show/16460325-can-the-poor-save (accessed on 23 February 2020).

Sharpe, William F., Gordon J. Alexander, and Jeffrey W. Bailey. 1999. Investments, 6th ed. Upper Saddle River: Prentice-Hall. Available online: http://en.bookfi.net/book/1426630 (accessed on 23 February 2020).

Tregub, A. Ya., R. V. Grigoryan, A. V. Timofeyev, K. V. Zverev, E. E. Andreeva, and Yu. E. Rodionov. 2016. Russian Stock Market: 2016. Events and Facts. Available online: http://www.naufor.ru/tree.asp?n=4333 (accessed on 23 February 2020).

Tversky, Amos, and Daniel Kahneman. 1981. The framing of decisions and the psychology of choice. Science 211: 453-58. [CrossRef]

Zaman, Ashraf A. 2017. Distributional Impacts of Canada's Tax-Free Savings Accounts. Canadian Public Policy 43: 331-49. [CrossRef]

Zapevalova, Ekaterina S. 2017. Modeling the yield of Russian government bonds depending on the share of non-residents in trading as a source of liquidity. Perm University Herald. ECONOMY 12: 218-33. [CrossRef]

(C) 2020 by the authors. Licensee MDPI, Basel, Switzerland. This article is an open access article distributed under the terms and conditions of the Creative Commons Attribution (CC BY) license (http://creativecommons.org/licenses/by/4.0/). 